\title{
Sensitivity of the Federal Fee For Managing Spent Fuel to Financial and Logistical Variations
}
M. K. White
M. A. Lewallen
E. T. Merrill
R. M. Fleischman

June 1978

Prepared for the U.S. Department of Energy under Contract No. EY-76-C-06-1830

Pacific Northwest Laboratory Operated for the U.S. Department of Energy by 


\title{
NOTICE
}

This report was prepared as an account of work sponsored by the United States Government. Neither this United States nor the Department of Energy, nor any of their emplovees, nor any of their contractors, subcontractors, or their employees, makes any warrarty, express or implied, of assumes ary legai liabiiny or responsibility for the accuracy, completeness or usefulness of any information, apparatus, product or pracess. disclosed, or represents that its use would not intringe privately cwaed rights.

The views, opinions and conclusions contained in this report are those of the contractor and do not necessarily represent those of the IJnited States Government or the United States Department of Energy.

\section{PACIFIC NORTHWEST LABORATORY operated by BATTELLE for the}

UNITED STATES DEPARTMENT OF ENERG $i$ Under Contract EY-76-C-06-1830

\author{
Printed in the United States of America \\ Avaliable lrom \\ National Technical Iniormation Service \\ United States Department of Commerce \\ 5285 Port Royal Road \\ Springtield, Virginia 22151
}

Price: Printed Copy 5

: Microtiche 5100

\begin{tabular}{|c|c|}
\hline thet & $\begin{array}{c}\text { NTIS } \\
\text { Selling Pr.ce }\end{array}$ \\
\hline $001-025$ & 54.00 \\
\hline $026-050$ & 54.50 \\
\hline 051.275 & $\$ 5.25$ \\
\hline $076-100$ & 56.00 \\
\hline $101-123$ & 5650 \\
\hline 126.750 & 57.25 \\
\hline $151-173$ & 58.00 \\
\hline 176.200 & 5500 \\
\hline $291-225$ & 59.25 \\
\hline $226-250$ & 50.30 \\
\hline $251 \cdot 205$ & 570.73 \\
\hline $278 \cdot 300$ & 511.00 \\
\hline
\end{tabular}


SENSITIVITY OF THE FEDERAL FEE

FOR MANAGING SPENT FUEL TO FINANCIAL

AND LOGISTICAL VARIATIONS

M. K. White

M. A. Lewallen

E. T. Merrill

R. M. Fleischman

June 1978

Prepared for

the U.S. Department of Energy

under Contract No. EY-76-C-06-1830

Pacific Northwest Laboratory

Richland, Washington 99352 


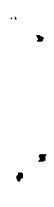


CONTENTS

1.0 INTRODUCTION

2.0 SUMMARY . . . . . . . . . . . . . . . . . . . 3

2.1 DEMAND VARIATION RESULTS. . . . . . . . . . . . 4

2.2 FACILITY VARIATION RESULTS . . . . . . . . . . . 5

2.3 COST RECOVERY VARIATION RESULTS . . . . . . . . . 6

2.4 FINANCIAL VARIATION RESULTS. . . . . . . . . . . . 7

2.5 SYSTEM PERFORMANCE VARIATION RESULTS. . . . . . . 8

3.0 SPENT FUEL MANAGEMENT SYSTEM DESCRIPTION . . . . . . . . . 9

3.1 AWAY FROM REACTOR (AFR) STORAGE FACILITIES. . . . . 9

3.2 TRANSPORTATION . . . . . . . . . . . . . . . 10

3.3 FUEL PACKAGING FACILITIES . . . . . . . . . . . . . 10

3.4 GEOLOGIC REPOSITORIES. . . . . . . . . . . . . 10

4.0 METHODOLOGY FOR FULL COST RECOVERY . . . . . . . . . 11

5.0 ReferenCE CASE. . . . . . . . . . . . . . . . . 13

5.1 SPENT FUEL STORAGE/DISPOSAL REQUIREMENTS . . . . . . 13

5.2 SPENT FUEL STORAGE/DISPOSAL CAPABILITY . . . . . . 13

5.3 SPENT FUEL MANAGEMENT COSTS. • . . . . . . . . . . 14

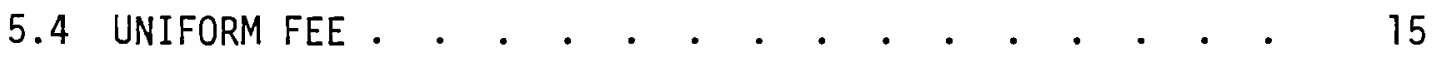

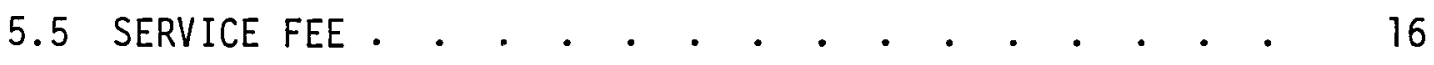

6.0 PARAMETERIZATION STUDIES . . . . . . . . . . . . . . 17

6.1 STORAGE/DISPOSAL DEMAND VARIATION. • . . • • . . . 17

6.2 STORAGE/DISPOSAL FACILITY VARIATIONS. . . . . . . 20

6.3 COST RECOVERY METHODOLOGY VARIATIONS. . . . . . . 23

6.4 FINANCIAL VARIATIONS . . . . . . . . . . . . . 24 
7.0 ANALYSIS OF ABNORMAL SYSTEM PERFORMANCE . . . . . . . 27

7.1 UNPLANNED DELAY OF THE FIRST REPOSITORY. . . . . . . . 27

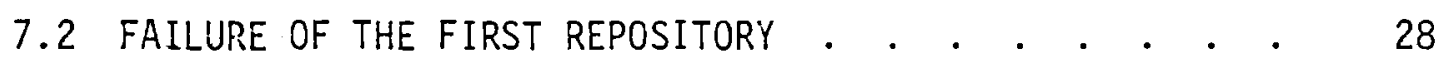

REFERENCES. • . . . . . . . . . . . . . . . . . 31

APPENDIX A - FACILITY COST DATA. . . . . . . . . . . . A- A

APPENDIX B - SPENT FUEL LOGISTICS . . . . . . . . . . . . B-1 


\subsection{INTRODUCTICN}

In October of 1977, the Department of Energy (DOE) announced a spent fuel policy whereby the Federal Government would accept and take title to commercial reactor spent fuel for a one-time fee to utility companies owning nuclear power reactors. This policy action was taken to resolve the uncertainty regarding ultimate spent fuel disposition in light of President Cärter's earlier decision to indefinitely defer commercial reprocessing of spent nuclear fuel. A one-time fee concept was selected so that the costs of spent fuel disposition could be confidently accounted for in the determination of electricity cost. This concept requires that the Federal Government fully recover all costs incurred from managing the spent fuel and that all further liability of the utilities will cease with delivery of the fuel and payment of the fee.

Upon announcement of the spent fuel policy, efforts were initiated to make a timely determination of a fee for purpose of discussion in the public sector. The Office of Waste Isolation awarded a contract to TRW Energy Systems to develop a methodology and comprehensive data base, and DOE commissioned Battelle Pacific Northwest Laboratories (PNL) to examine the sensitivity of the one-time fee to variations in the financial and logistical components of the calculation. In order to do this, PNL developed a methodology and data base for calculating the fee independently and in parallel with the work reported by TRW. (1) It is noteworthy that despite the independence of these two efforts, the methodologies developed are markedly similar, and the known differences in cost data do not cause significant differences in the calculated fee.

The engineering cost estimates for fuel handling and management facilities and long term utility plans for transferring fuel to the Federal Government are preliminary at this time. The cost data used in this report are estimates that were arrived at through consultations with organizations responsible for developing engineering cost estimates for related DOE spent fuel and waste handling programs. Therefore, these estimates are representative of the best information available at the time this work was performed. 
The one-time fee will not be established until sometime in the future when DOE is ready to enter into firm contractual commitments with utilities, and the actual fee paid by utilities will be that in effect at the time of fuel transfer. At that time, many of the current uncertainties will be resolved. This report and other near term activities to develop methodologies and technical bases for establishing the fee should be viewed as serving the process of public discussion regarding how the Federal Government should proceed to policy implementation. In particular, the results presented here are intended to display the sensitivities of the fee calculation to parametric variation of key components so that in the process of establishing a fee the sensitivity of important assumptions will be known to those engaged in the discussion and decision making process. The results quoted herein are in no way intended to represent a recommended fee to be adopted by the Federal Govemment. 


\subsection{SUMMARY}

- Three types of fees for federal spent fuel management service were calculated for a reference case and a number of variations. These fee types are a uniform fee applicable to all customers, a fee for disposal of spent fuel, and a fee for interim storage plus disposal of spent fuel. The results ranged from $\$ 124 / \mathrm{kg}$ to $\$ 256 / \mathrm{kg}$ for the uniform fee, $\$ 112 / \mathrm{kg}$ to $\$ 213 / \mathrm{kg}$ for the disposal fee, and $\$ 144 / \mathrm{kg}$ to $\$ 319 / \mathrm{kg}$ for the storage plus disposal fee.

The reference case assumed that spent fuel would first be received by the government in 1983 at a 5,000 MT away-from-reactor (AFR) basin. The first repository (45,000 MT) was assumed ready for fuel in 1988, and the second $(100,000$ MT) in 1997. Fuel would be transferred from the AFR basins to the repositories before the year 2000. Discounted costs for disposing of all fuel received by 2000 were levelized over the appropriate throughputs from 1983 to 2000 to determine the fees. Al1 costs were expressed in 1978 dollars and a $6.5 \%$ discount rate was used. The reference case results in fees of $\$ 129 / \mathrm{kg}$ for the uniform fee $\$ 117 / \mathrm{kg}$ for disposal and $\$ 232 / \mathrm{kg}$ for storage plus disposa?.

The sensitivity cases were grouped in five general categories of variations from the reference case assumptions:

1. Demand for storage/disposal services

2. Facility schedules and characteristics

3. Methodology for calculating the fee

4. Discount rate and AFR financing

6. Delays or failure of the first repository.

The scope and magnitude of the variations considered were intended to reasonably bound the bases for estimating the spent fuel management fee. No known key parameters were purposely ignored in this analyses. The results are discussed briefly below. More detailed discussions of the technical basis, methodology and results of this analysis are discussed in the following sections. 


\subsection{DEMAND VARIATION RESULTS}

The reference case results were compared with those for several cases in which the demand for spent fuel storage was varied. The first two cases shown in Figure 1 show the impact of variation in AFR basin requirements. Cases 3 and 4 show the impact of altering the amount of fuel requiring disposal. The uniform fee, disposal fee, and storage plus disposal fee are shown for the reference case and each variation case. Varying the demand for disposal causes a greater change than varying AFR basin requirements.

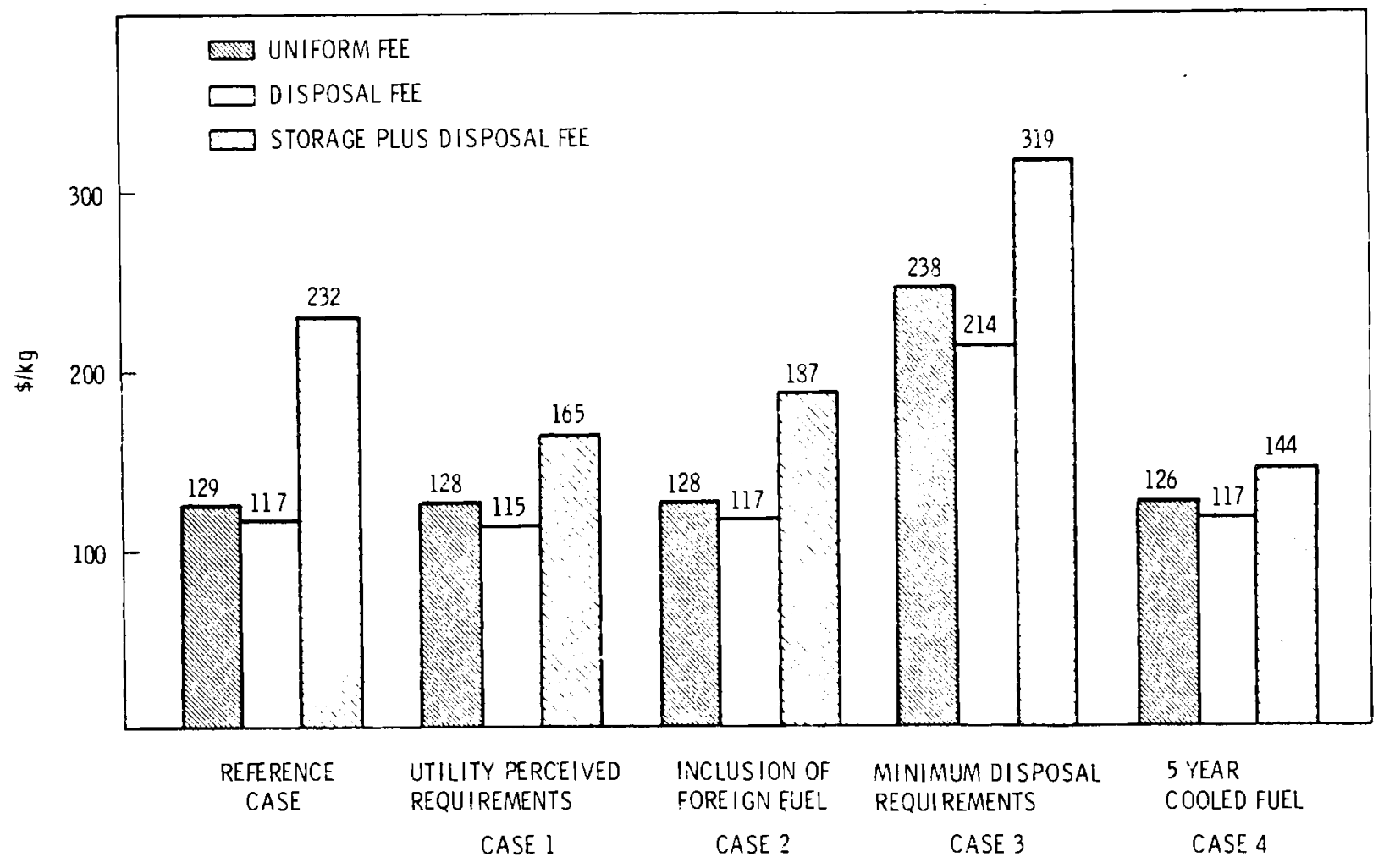

FIGURE 1. Demand Variation Results 


\subsection{FACILITY VARIATION RESULTS}

Facility startup and operating variation results are shown in Figure 2. Cases 5 and 6 demonstrate the effect of varying the repository startup date, and Case 7 shows the effect of altered repository size. The greatest variation from the reference case occurred when the first repository was delayed until 1993, but in general the fee calculation was insensitive to these variations. Delaying repository startup increased the uniform and disposal fees while decreasing the storage plus disposal fee. This decrease is due to increased AFR basin utilization. The effect of increasing the size of the first repository was slight.

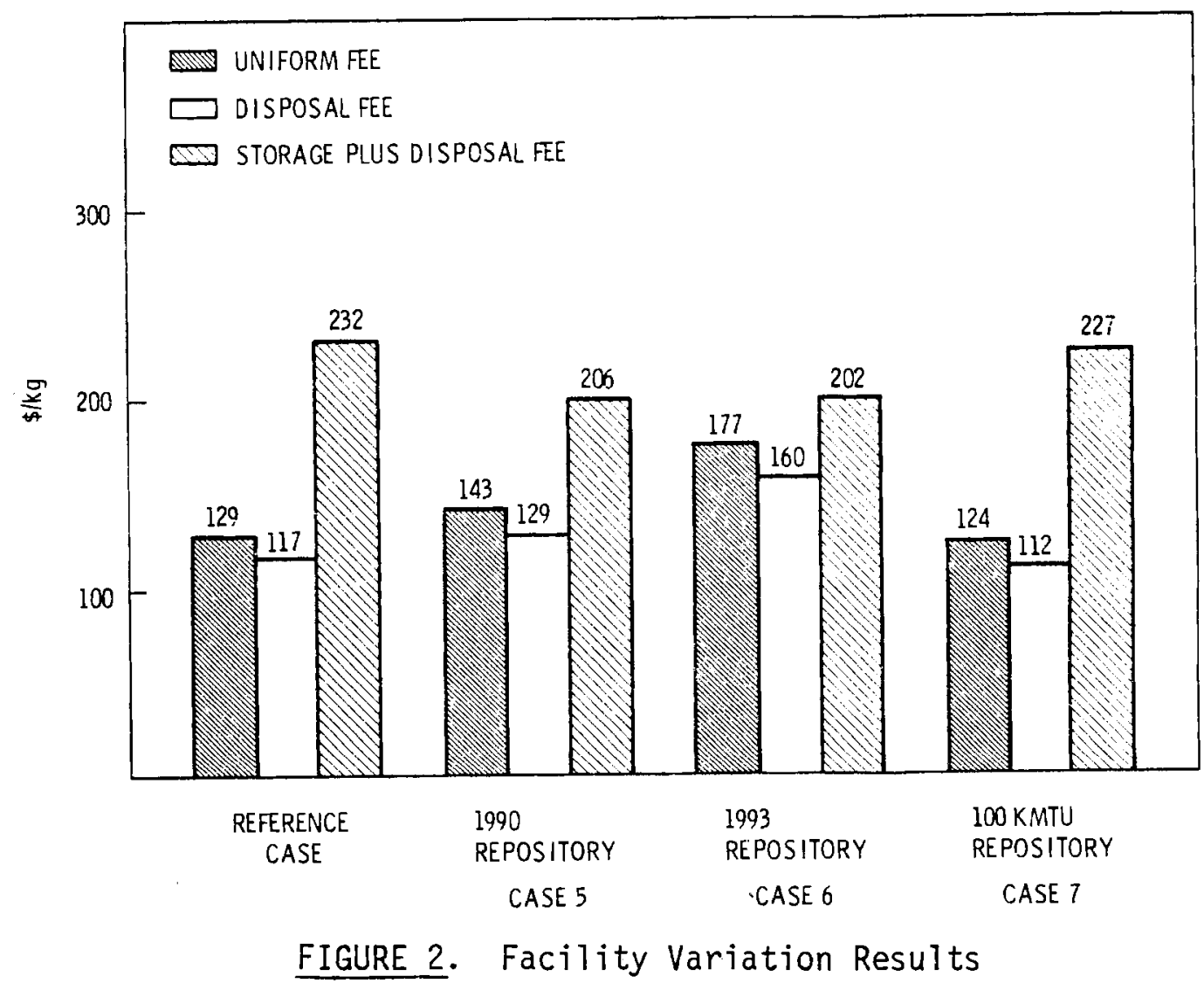




\subsection{COST RECOVERY VARIATION RESULTS}

A comparison was made between the reference case fees and the fees calculated by altering the cost levelization methodology. In Case 8 the levelization period was shortened to 1983 to 1992 (10 years). This caused increases in the fees due to allocation of early costs to fewer customers. Case 9 shows the impact of considering only the costs and throughputs for the first repository in the fee calculation. This caused only minor variation in the fees.

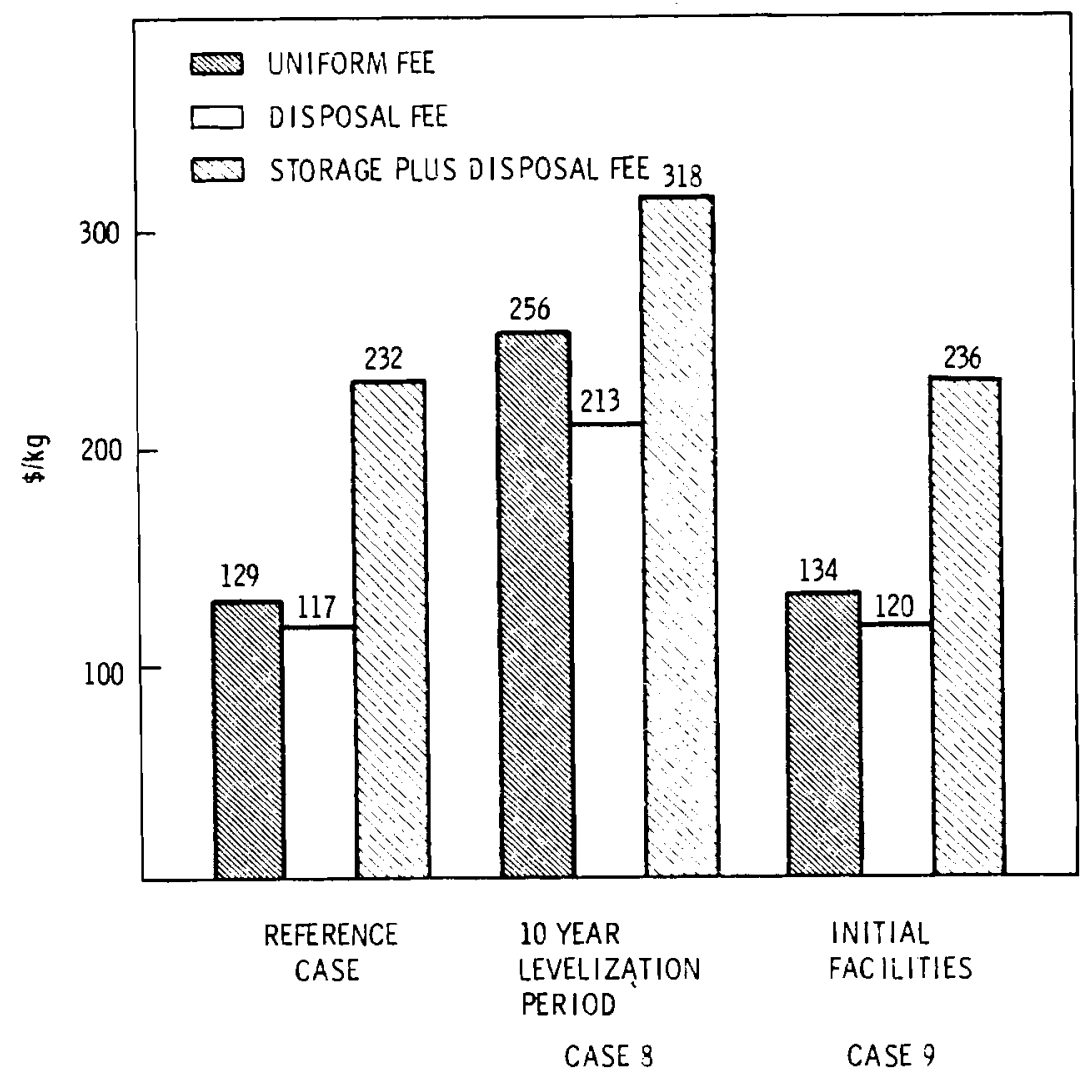

FIGURE 3. Methodology Variation Results 


\subsection{FINANCIAL VARIATION RESULTS}

The results in Figure 4 show how the calculated fee changes when selected financial assumptions are varied. The discount rate used in the fee calculation was arbitrarily varied in Case 10 from $0 \%$ to $10 \%$ to show the sensitivity of the fees to this parameter. Case 11 shows the impact of private rather than federal financing of AFR basins. The uniform fee and storage plus disposal fees increase to provide an after tax return on private capita?.

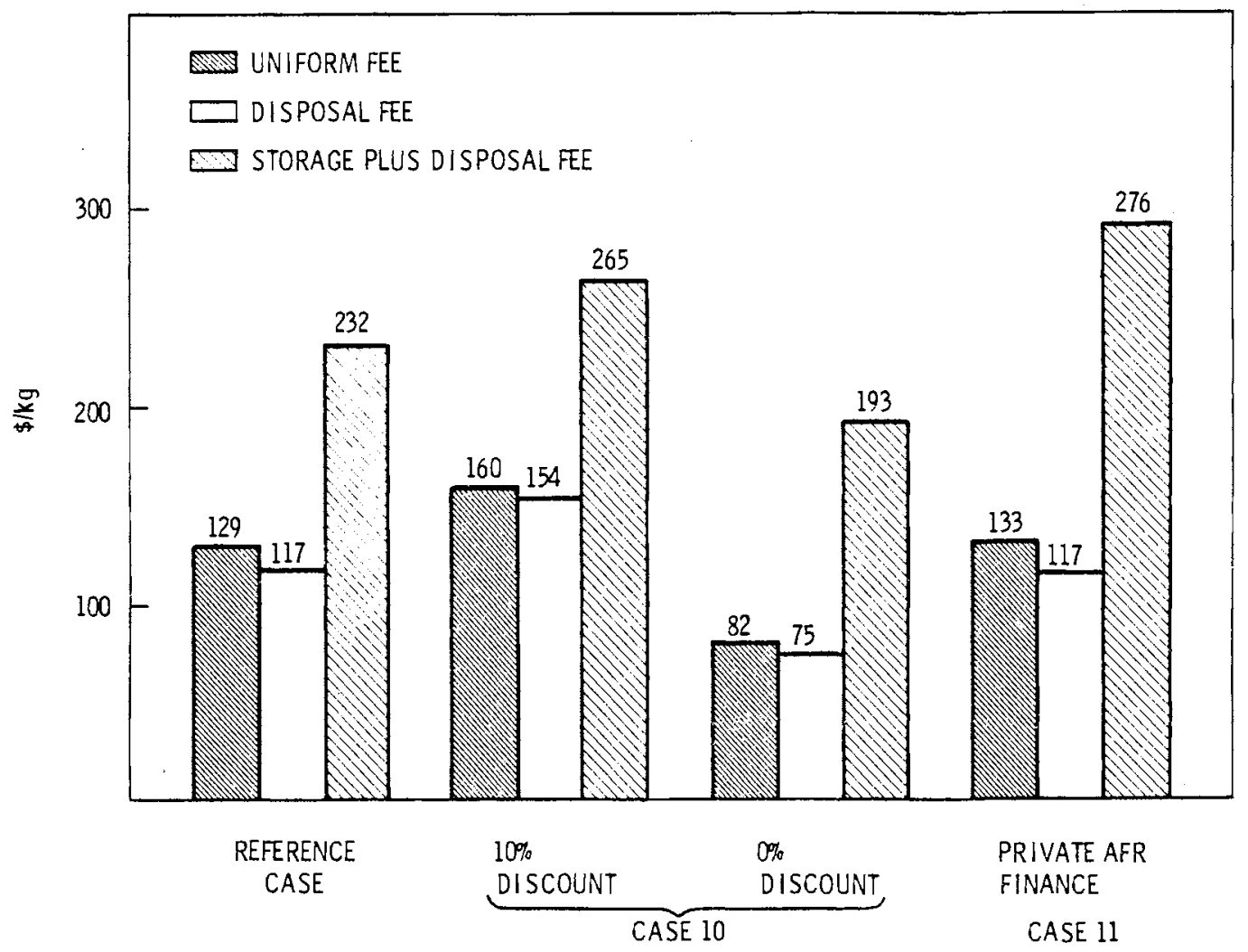

FIGURE 4. Financial Variation Results 


\subsection{SYSTEM PERFORMANCE VARIATION RESULTS}

The final group of variations from the reference case illustrates the impact of schedule delays (with cost overrun) of the first repository (Cases 12-13), and operational failure at the first repository (Cases 14 and 15). Only the uniform fee is shown (Figure 5) for these cases, since the uniform fee is a measure of the difference in system costs under these abnormal conditions.

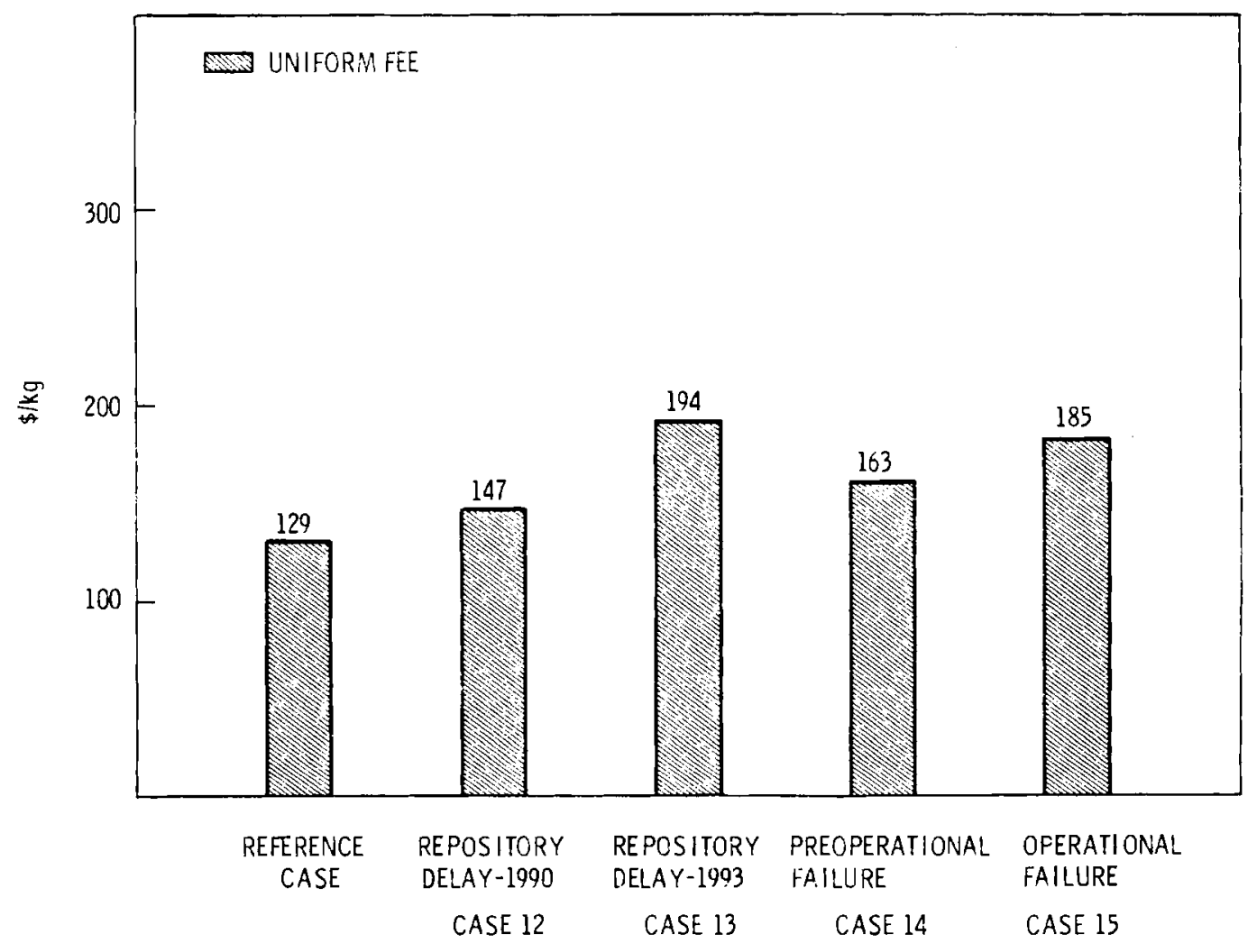

FIGURE 5. System Performance Variation Results 


\subsection{SPENT FUEL MANAGEMENT SYSTEM DESCRIPTION}

A number of assumptions were made to define the spent fuel management system. It was assumed that beginning in 1983 the Federal Government would begin to accept and take title to spent fuel voluntarily delivered by utilities. This fuel would be stored in a large water basin facility constructed away from reactors (AFRs) until the first geologic repository becomes available (1986 in the reference case). After that time, spent fuel would be packaged in canisters and stored in a geologic repository, subject to throughput limitations at the repository. Fuel initially stored in the AFR basin would be shipped to the packaging/repository location for disposal as soon as possible.

The sensitivity of the one-time charge to many of the assumptions which were made about the characteristics and performance of the spent fuel management system are investigated later in this report. General descriptions of each of the major components of the system are given below.

\subsection{AWAY FROM REACTOR (AFR) STORAGE FACILITIES}

The AFR facility concept was based on current design work being performed at the Savannah River Laboratory. ${ }^{(2)}$ This facility has the capability to receive spent fuel, transfer the fuel to a water pool, decontaminate the shipping cask, and perform all activities associated with eventual unloading of the facility. The first facility was assumed to have an adequately sized initial capacity which was expandable in increments of 1000 MT to a maximum of 15,000 MT. The receipt rate was assumed to be $2000 \mathrm{MT} / \mathrm{yr}$, which may be expanded to $3000 \mathrm{MT} / \mathrm{yr}$. Additional AFR capacity would be added to the system as required. In the parametric analysis, both privately financed and government financed AFR basins were considered. 


\subsection{TRANSPORTATION}

Initial delivery of spent fuel to spent fuel handling facilities was assumed to be the responsibility of the utilities. Costs for transfer of fuel from the AFR basin to the repository site were based on dedicated trains using IF-300 casks for an average one way trip of 1600 miles. (1) Transportation services including casks were assumed to be provided by the private sector.

\subsection{FUEL PACKAGING FACILITIES}

The fuel packaging facility design was based on work performed by Rockwell Hanford Operations. ${ }^{(3)}$ These facilities were collocated with the geologic repository. They have the capability to place the fuel in canisters, weld the canisters closed, test the integrity of the canister, and transfer the fuel to the shaft of the repository.

\subsection{GEOLOGIC REPOSITOP.IES}

The geologic repository was assumed to be a 2000 acre bedded salt facility based on design studies performed by the Office of Waste Isolation. The facility includes features required to mine and store the salt, receive packaged spent fuel canisters, transport canisters down the shaft and place them in salt formations, and backfill with salt. For the initial five years the repository was operated in a retrievable mode at roughly $30 \%$ of design throughput capability. The first repository was loaded to 45,000 MT, which is slightly less than one half of design capacity. The second repository, also a 2000 acre bedded sait design, was assumed to be capable of operating at current design specification. In the parametric analysis the sensitivity of the spent fuel management costs to conservative design features of the initial repository was investigated. 


\subsection{METHODOLOGY FOR FULL COST RECOVERY}

The fundamental premise in formulating a fee for spent fuel management is full cost recovery. When fuel is received by the government a "one-time" fee must be collected to fully recover all capital, operating, debt service, government overhead, and research and development costs.

A methodology to calculate this fee, or levelized charge, must align with established business procedures. The methodology used to calculate a levelized charge for spent fuel storage/disposal is similar to that used to calculate the separative-work-unit (SWU) charge. Full cost recovery is the principle feature of both calculations.

Full cost recovery can be expressed in equation form as:

$$
\begin{aligned}
\text { Discounted Cost } & =\text { Discounted Revenue } \\
& =\text { Levelized Charge } \times \text { Discounted Throughput }
\end{aligned}
$$

Therefore, the desired levelized charge is:

Level ized Charge $=\frac{\text { Discounted Cost }}{\text { Discounted Throughput }}$

Determining a fee or fees for governmerit spent fuel management services depends on the philosophy adopted for fully recovering government costs. To calculate a uniform fee to be paid by a 11 customers, the appropriate throughputs and costs are the total fuel delivered to the government within some specified period and the total costs associated with storage and eventual disposal of that fuel. If an appropriate fee is to be determined for some component of the spent fuel management system, the costs and throughputs of that particular component should be used in the equation.

In any application of the levelization equation, several conventions must be established. There is some latitude in each application of the levelization process, as long as care is taken to conserve the total system balance between discounted costs and discounted revenues. The factors which must be considered are: 
1. Discount rate - The levelization process requires discounting of cash flows for both costs and revenues. The discount rate should reflect the cost of capital to the operator providing the services.

2. Planning Period - The period of time for which costs are levelized over throughput must be selected. There are no "rules" for determining the appropriate period. In general, the period should be long enough to lessen the effects of any unusual perturbations in estimated cost or throughput, but short enough so that the estimates are reliable.

3. Costs - The "discounted costs" term of the levelization equation may be expanded to:

$$
\begin{aligned}
\text { Discounted Costs }= & \text { Present Value of [Initial System Value + } \\
& \text { Cash Expenditures - Ending System Value] }
\end{aligned}
$$

The initial system value refers to any unrecovered costs incurred prior to the levelization period. The cash expenditures included are $a 11$ of those associated with managing the spent fuel received during the period, even if they are to be incurred after the end of the period. The ending system value adjusts the costs allocated to the customers of the period by taking credit for the remaining value of capital facilities at the end of the period.

4. Cost Data - Projections must be made of the costs of future facilities and activities. The attached Appendix gives the cost data used for spent fuel management activities in this report. No attempt has been made to account for inflation and all costs (and revenues) are expressed in 1978 dollars.

5. Discounted Throughput - This term varies with the period considered and the choice of uniform, disposal, or storage plus disposal fee calculation. 


\subsection{REFERENCE CASE}

\subsection{SPENT FUEL STORAGE/DISPOSAL REQUIREMENTS}

Earlier this year the Nuclear Regulatory Commission issued the Draft Generic Environmental Impact Statement on Handling and Storage of Spent Light water Power Reactor Fuel. (4) As part of their analysis, NRC calculated post reactor basin storage requirements for several combinations of assumptions. For this analysis the calculated storage requirements which result when all reactors install compact spent fuel racks and maintain the capability for full core discharge were used. It was assumed that the federal government would receive fuel at the rate calculated by NRC during the period interim water basin storage was required. As soon as the repository becomes available, it is assumed that fuel will be received at the design receipt capacity. The receipts and shipments of fuel at spent fuel storage and disposal facilities is shown in Table 1.

\subsection{SPENT FUEL STORAGE/DISPOSAL CAPABILITY}

The first receipt of fuel at a federal spent fuel storage facility was assumed to occur in 1983 at a 5,000 MT capacity away-from-reactor (AFR) basin capable of receiving 2,000 MT per year. A11 fuel accepted by the government prior to the availability of the first repository would be received at this basin.

The first repository was assumed ready for fuel receipt in 1986. Fuel receipt was constrained to 1,800 MT/yr for the first five years of operation of this repository to provide a period of "proof" of the geologic properties of the site. After this five year period fuel could be received at a maximum receipt rate of $6,000 \mathrm{MT} / \mathrm{yr}$. It was conservatively assumed that this repository would operate at low thermal loading which would allow disposal of approximately 45,000 MT of fuel. The second repository first receives fuel in 1997. Increased thermal loading would allow for disposal of approximately 100,000 MT of fuel at this repository. A larger maximum receipt rate of 9,000 MT/yr was assumed for the second and subsequent repositories. Fuel in the federal storage basin would be transferred to the repository as soon as possibie. 
TABLE 1. Allocation of Spent Fuel to Federal Facilities (MT)

\begin{tabular}{|c|c|c|c|c|}
\hline & $\begin{array}{l}\text { Fue } 1 \\
\text { From Reactors } \\
\end{array}$ & $\begin{array}{l}\text { Receipt (Shipments) } \\
\text { at Storage Basin } \\
\end{array}$ & $\begin{array}{r}\text { Receipt at } \\
\text { Repository } 1 \\
\end{array}$ & $\begin{array}{r}\text { Receipt at } \\
\text { Repository } 2 \\
\end{array}$ \\
\hline Backlog & 659 & & & \\
\hline 1983 & 319 & 978 & & \\
\hline 1984 & 429 & 429 & & \\
\hline 1985 & 506 & 506 & & \\
\hline 1986 & 605 & 605 & & \\
\hline 1987 & 655 & 655 & & \\
\hline 1988 & 698 & $(1102)$ & 1800 & \\
\hline 1989 & 752 & $(1048)$ & 1800 & \\
\hline 1990 & 850 & (950) & 1800 & \\
\hline 1991 & 1727 & (73) & 1800 & \\
\hline 1992 & 1800 & & 1800 & \\
\hline 1993 & 6000 & & 6000 & \\
\hline 1994 & 6000 & & 6000 & \\
\hline 1995 & 6000 & & 5000 & \\
\hline 1996 & 6000 & & 6000 & \\
\hline 1997 & 6000 & & 3000 & 3000 \\
\hline 1998 & 6000 & & 3000 & 3000 \\
\hline 1999 & 6000 & & 3000 & 3000 \\
\hline 2000 & 6000 & & 2740 & 3260 \\
\hline TOTAL & 57,000 & 3,173 & 44,740 & 12,260 \\
\hline
\end{tabular}

\subsection{SPENT FUEL MANAGEMENT COSTS}

Six categories of spent fuel management costs were considered. These are listed below and discussed briefly. Appendix A gives a more detailed breakdown and discussion of these costs.

1. AFR - It was assumed that AFR storage basins were built and operated by the government. Costs were included for building, operating and decommissioning these facilities. 
2. Transportation - This cost component is only experienced by fuel transferred from the AFR basin to the repository. The cost of shipping fuel from reactors to the AFR basin or repository is borne by the utility.

3. Packaging - Packaging facilities were assumed collocated with the repositories. One PWR or two BWR assembiies are packaged in a $1 / 2$ inch wall carbon steel canister.

4. Repository - These costs are based on a 2,000 acre bedded salt repository. The thermal loading, and thus the capacity, of the first repository is limited to slightly less than half of the reference design basis.

5. Research and Development - This category provides for recovery of federal funds expended in achieving spent fuel management capability.

6. Government Overhead - This cost component reflects the ongoing costs of managing the spent fuel storage/disposal activity.

\subsection{UNIFORM FEE}

These component costs were levelized over all projected fuel receipts between 1983 and 2000, using a $6.5 \%$ discount rate to arrive at a uniform fee for all customers. The $6.5 \%$ discount rate represents the government bond rate. Costs associated with all facilities required in this period were included. The unrecovered capital investment in facilities built and available for use after the end of the period (2000) were taken as a credit in the calculation.

The calculated result for the reference case was $\$ 128.50 / \mathrm{kg}$, as shown in Table 2. The fee is partitioned into capital and operating components, as is shown in Table 2. Transportation, R\&D and overhead have been treated as operating costs. The fee components are rounded to the nearest $\$ 0.50 / \mathrm{kg}$. This degree of accuracy was reported to retain relative component proportions, but does not imply that level of confidence in the absolute magnitudes of the charge components. 
TABLE 2. Levelized Charge Components

for Reference Case $(\$ / \mathrm{kg})$

\begin{tabular}{|c|c|c|c|}
\hline & Capital & Operating & Total \\
\hline AFR Basin & 9.00 & 2.00 & 11.00 \\
\hline Transportation & - & 2.50 & 2.50 \\
\hline Packaging & 16.50 & 16.50 & 33.00 \\
\hline Repository & 25.00 & 25.00 & 50.00 \\
\hline$R \& D$ & - & 26.50 & 26.50 \\
\hline Overhead & - & 5.50 & 5.50 \\
\hline TOTAL & 50.50 & 78.00 & 128.50 \\
\hline
\end{tabular}

\subsection{SERVICE FEE}

To calculate the appropriate fee if each utility customer pays for only those services its fuel requires, each component cost was levelized over a 11 users of that component. This resulted in two classes of fee, a disposal only fee and a storage plus disposal fee. As in the uniform fee calcuiation, all costs associated with managing fuel received prior to 2000 were included.

These results are shown in Table 3. The packaging and repository components of these two fees are slightly different due to the storage and disposal customers prepaying for these services when they deliver their fuel to the AFR basin.

TABLE 3. Service Fee Components for Reference Case $(\$ / \mathrm{kg})$

\begin{tabular}{|c|c|c|}
\hline & $\begin{array}{l}\text { Disposal } \\
\text { Fee } \\
\end{array}$ & $\begin{array}{l}\text { Storage Plus } \\
\text { Disposal Fee }\end{array}$ \\
\hline AFR Basin & - & 104.00 \\
\hline Transportation & - & 26.00 \\
\hline Packaging & 33.50 & 27.50 \\
\hline Repository & 51.50 & 42.00 \\
\hline R\&D & 26.50 & 26.50 \\
\hline Overhead & 5.50 & 5.50 \\
\hline TOTAL & $\overline{117.00}$ & 231.50 \\
\hline
\end{tabular}




\subsection{PARAMETERIZATION STUDIES}

Several categories of variation from the reference case were analyzed to determine their impact on the calculated spent fuel storage/disposal fees. These categories of variation and the individual variation cases are discussed in the following section.

\subsection{STORAGE/DISPOSAL DEMAND VARIATION}

The demand for federal spent fuel storage/disposal services was varied by considering changes in reactor basin storage period and changes in AFR basin storage requirements.

Case 1 - Utility Perceived Requirements

In response to a DOE survey, nuclear utilities indicated a need for post reactor basin storage of 10,690 MT of spent fuel by 1988. To examine the impact of varying AFR basin requirements on the calculated fee, the utility perceived storage requirements were assumed instead of the NRC calculated requirements in the reference case. The mass flows for this case are given in Appendix B. Table 4 gives the result of the fee calculations. The uniform fee is nearly the same as in the reference case $(\$ 128.50 / \mathrm{kg})$, with the cost of increased AFR basin storage offset by decreases in the other components due to higher early revenues. The same is true of the disposal only fee. However, the storage plus disposal fee is reduced considerably from the reference case $(\$ 231.50 / \mathrm{kg})$. This is due mainly to economies of scale for larger AFR basins (10,000 MTU versus 5,000 MTU) and improved AFR basin utilization (97\% versus $63 \%)$. 
TABLE 4. Calculated Fees for Utility Ferceived Storage Requirements $(\$ / \mathrm{kg})$

\begin{tabular}{|c|c|c|c|}
\hline & Uniform Fee & Disposal Fee & $\begin{array}{l}\text { Storage Plus } \\
\text { Disposal Fee }\end{array}$ \\
\hline AFR Basin & 17.00 & - & 59.50 \\
\hline Transportation & 6.00 & - & 20.50 \\
\hline Packaging & 30.00 & 33.50 & 22.00 \\
\hline Repository & 45.50 & 51.50 & 33.50 \\
\hline$R \& D$ & 24.50 & 24.50 & 24.50 \\
\hline Overhead & 5.00 & 5.00 & 5.00 \\
\hline TOTAL & 128.00 & 114.50 & 165.00 \\
\hline
\end{tabular}

Case 2 - Storage/Disposal for Foreign Fuel

This case shows the fee sensitivity of providing storage and disposal services for 300 to 500 MT of foreign spent fuel per year until 1990. The logistics for this case are shown in Appendix B. Table 5 shows that providing such services would cause little variation of the uniform fee and the disposal fee, but would decrease the storage plus disposal fee due to more efficient utilization of AFR basin capacity.

TABLE 5. Calculated Fees for Foreign Participation

\begin{tabular}{|c|c|c|c|}
\hline & Uniform Fee & Disposal Fee & $\begin{array}{l}\text { Storage Plus } \\
\text { Disposal Fee }\end{array}$ \\
\hline AFR Basin & 11.50 & - & 70.50 \\
\hline Transportation & 4.00 & - & 23.00 \\
\hline Packaging & 32.00 & 33.50 & 24.50 \\
\hline Repository & 49.00 & 51.50 & 37.50 \\
\hline R\&D & 26.00 & 26.00 & 26.00 \\
\hline Overhead & 5.50 & 5.50 & 5.50 \\
\hline TOTAL & 128.00 & 116.50 & 187.00 \\
\hline
\end{tabular}


Case 3 - Minimum Storage/Disposa? Requiremerits

The reference case assumes that spent fuel will be shipped to the federal government at the design receipt rate for disposal facilities once those facilities are available. This case examines the fee impact of continuing to receive fuel at the rate indicated in the NRC analysis rather than the design receipt rate. The altered scenario requires disposal of approximately 21,000 MT of spent fuel by 2000 rather than the 57,000 MT in the reference case. The logistics for this case are given in Appendix $B$. Table 6 shows that the iripact of altering the receipt assumption is an increase in all three fees due to a decreased amount of fuel over which to amortize costs.

TABLE 6. Calculated Fees with Minimum Fuel Receipts

\begin{tabular}{|c|c|c|c|}
\hline & Uniform Fee & Disposal Fee & $\begin{array}{l}\text { Storage Plus } \\
\text { Disposal Fee }\end{array}$ \\
\hline AFR Basin & 26.00 & - & 104.00 \\
\hline Transportation & 6.50 & - & 26.00 \\
\hline Packaging & 45.50 & 48.50 & 39.50 \\
\hline Repository & 82.00 & 87.00 & 71.00 \\
\hline$R \& D$ & 64.50 & 64.50 & 64.50 \\
\hline Overhead & 13.50 & 13.50 & 13.50 \\
\hline TOTAL & 238.00 & 213.50 & 378.50 \\
\hline
\end{tabular}

\section{Case 4 - Storage and Disposal of Five Year Cooled Fuel}

The reactor discharge schedule assumed by the NRC in computing the post-reactor basin storage requirements for the reference case was used to compute the storage and disposal requirements for a scenario where fuel is transferred to the federal government five years after discharge. This assumption leads to storage and disposal of a similar amount of spent fue?, by 2000 (58,900 MT compared with 57,000 MT in the reference case), but accomplishes this transfer of fuel at a higher initial rate. Approximately 14,000 MT AFR basin capacity is required in this case. The specific case 
logistics are given in Appendix B. Table 7 gives the calculated fees for this case. They are approximately the same as the reference case, with the exception that the storage plus disposal fee is lower due to AFR basin economies of scale and more efficient basin utilization.

\section{TABLE 7. Calculate Fees for Storage and Disposal of} Five Year Cooled Fuel

\begin{tabular}{|c|c|c|c|}
\hline & Uniform Fee & Disposal Fee & $\begin{array}{l}\text { Storage PTus } \\
\text { Disposal Fee }\end{array}$ \\
\hline AFR Basin & 16.50 & - & 47.50 \\
\hline Transportation & 6.50 & - & 18.00 \\
\hline Packaging & 30.50 & 36.00 & 20.50 \\
\hline Repository & 45.50 & 54.00 & 31.00 \\
\hline$R \& D$ & 22.50 & 22.50 & 22.50 \\
\hline Overhead & 4.50 & 4.50 & 4.50 \\
\hline TOTAL & 126.00 & 117.00 & 144.00 \\
\hline
\end{tabular}

Summary of Storage/Disposal Demand Sensitivities

The cases examined indicate that the uniform fee and disposal fee are sensitive to changes in the total demand for services. These calculated fees increased significantly when the assumed demand was decreased (Case 3 ). The storage plus disposal fee showed sensitivity to the amount of AFR basin storage required. The AFR component of that fee is affected by the utilization of the basin. In Cases 1 and 3 slightly greater than 3,000 MT of a 5,000 MT capacity basin are used, resulting in a high AFR component of the storage plus disposal fee. In Cases 2 and 4 the AFR basins are used more effectively, and a corresponding decrease in the fee is observed.

\subsection{STORAGE/DISPOSAL FACILITY VARIATIONS}

The repository startup date and capacity were varied to determine the sensitivity of the calculated fee to those assumptions. 
Case 5 - Planned 1990 Repository

Delaying the first repository startup until 1990 would require storing approximate1y 4,600 MT of spent fuel in the AFR basin, which may be accommodated by the 5,000 MT basin assumed in the reference cases. The logistics for a 1990 repository are shown in Appendix B. Table 8 gives the calculated fees for this case. The uniform fee and disposal fees are increased from the reference case due to a decreased amount of spent fue1 (51,000 MT compared with 57,000 MT) over which to levelize fixed costs. The AFR basin component of the storage plus disposal fee is reduced because of greater utilization of the basin.

TABLE 8. Calculated Fees for a Planned 1990 Repository Startup

\begin{tabular}{|c|c|c|c|}
\hline & Uniform Fee & Disposal Fee & $\begin{array}{l}\text { Storage Plus } \\
\text { Disposal Fee }\end{array}$ \\
\hline AFR Basin & 14.50 & - & 79.00 \\
\hline Transportation & 4.00 & - & 22.50 \\
\hline Packaging & 32.00 & 34.00 & 24.50 \\
\hline Repository & 50.00 & 53.00 & 38.00 \\
\hline$R \& D$ & 34.50 & 34.50 & 34.50 \\
\hline Overhead & 7.50 & 7.50 & 7.50 \\
\hline TOTAL & 142.50 & 129.00 & 206.00 \\
\hline
\end{tabular}

Case 6 - Planned 1993 Repository

Further delaying the first repository until 1993 would require AFR basin storage of approximately 7500 MT of spent fuel and allow for disposal of 27,000 MT of spent fuel by 2000 . The logistics of this case are given in Appendix B. Table 9 shows the results for this case. Again, fixed costs are levelized over less fuel which increases the calculated uniform fee. 
TABLE 9. Calculated Fees for a Planned 1993 Startup

\begin{tabular}{|c|c|c|c|}
\hline & Uniform Fee & Disposal Fee & $\begin{array}{l}\text { Storage Plus } \\
\text { Disposal Fee }\end{array}$ \\
\hline AFR Basin & 26.00 & - & 62.50 \\
\hline Transportation & 7.50 & - & 18.50 \\
\hline Packaging & 28.50 & 34.00 & 20.00 \\
\hline Repository & 48.50 & 60.00 & 35.00 \\
\hline$R \& D$ & 54.50 & 54.50 & 54.50 \\
\hline Overhead & 11.50 & 11.50 & 11.50 \\
\hline TOTAL & 176.50 & 160.00 & 202.00 \\
\hline
\end{tabular}

Case 7 - 100,000 MT First Repository

The logistics for this case are the same as the reference case, except that the first repository has a larger capacity. This has the impact of increasing the credit for remaining facility capacity at the end of the levelization period (2000) for both the repository and packaging facilities. As shown in Table 10, the fee reduction is relatively smal1.

TABLE 10. Caiculated Fees for 100,000 MT First Repository

\begin{tabular}{|c|c|c|c|}
\hline & Uniform Fee & Disposal Fee & $\begin{array}{l}\text { Storage Plus } \\
\text { Disposal Fee }\end{array}$ \\
\hline AFR Basin & 11.00 & - & 104.00 \\
\hline Transportation & 2.50 & - & 26.00 \\
\hline Packaging & 30.50 & 31.00 & 25.50 \\
\hline Repository & 47.50 & 48.50 & 39.00 \\
\hline$R \& D$ & 26.50 & 26.50 & 26.50 \\
\hline Overhead & 5.50 & 5.50 & 5.50 \\
\hline TOTAL & 123.50 & 111.50 & 225.50 \\
\hline
\end{tabular}


The calculated fees are only moderately sensitive to short delays of the first repository (1988 to 1990) and increased capacity of the first repository. Delay of the first repository until 1993 increases the uniform and disposal fees significantly due to decreased fuel over which to levelize costs. This effect is offset for the storage plus disposal fee by the decreased AFR basin component resulting from more efficient basin utilization.

\subsection{COST RECOVERY METHODOLOGY VARIATIONS}

These cases demonstrate variations from the reference cost recovery calculation. Changes in levelization period and fees based only services at initial facilities were examined.

Case 8 - 1983-1992 Levelization Period

In the reference case costs and receipts for the period from 1983 to 2000 were considered in calculating the fees. This case examines the impact of caiculating the fees over a shorter period. Table 10 shows that this has the effect of increasing these fees. This is due to limited fuel receipts over which to levelize costs.

\section{TABLE 11. Calculated Fees for a 1983-1992 Levilization Period}

\begin{tabular}{lcccc} 
& Uniform Fee & & Disposal Fee & $\begin{array}{c}\text { Storage Plus } \\
\text { Disposal Fee }\end{array}$ \\
\cline { 2 - 3 } AFR Basin & 45.50 & & - & 104.00 \\
Transportation & 11.50 & - & 26.00 \\
Packaging & 44.50 & 49.50 & 40.50 \\
Repository & 79.50 & 88.50 & 72.50 \\
R\&D & 58.50 & 58.50 & 58.50 \\
Overhead & $\underline{16.50}$ & $\underline{16.50}$ & $\underline{16.50}$ \\
$\quad$ TOTAL & 256.00 & 213.00 & 318.00
\end{tabular}


Case 9 - Fee Based on Costs and Throughput of Initial Facilities

This case examines the impact of considering, in the fee calculation, only the projected costs and throughput for fuel entering the first repository. As shown in Table 12, this results in an increased fee since AFR basin costs, transportation, R\&D, and overhead must be levelized over a decreased throughput.

\section{TABLE 12. Calcuiated Fee Based on} Initial Facilities $(\$ / \mathrm{kg})$

\begin{tabular}{lcccc} 
& Uniform Fee & & Disposal Fee & $\begin{array}{c}\text { Storage Plus } \\
\text { Disposal Fee }\end{array}$ \\
\cline { 2 - 3 } AFR Basin & 13.00 & & - & 104.00 \\
Transportation & 3.00 & & - & 26.00 \\
Packaging & 30.50 & & 31.50 & 25.50 \\
Repository & 48.50 & & 50.00 & 41.00 \\
R\&D & 32.00 & & 32.00 & 32.00 \\
Overhead & 7.00 & & 7.00 & 7.00 \\
$\quad$ TOTAL & 134.00 & & 119.50 & 235.50
\end{tabular}

Summary of Cost Recovery Methodology Sensitivities

Calculating the fee based on initial facilities limits the throughput over which to levelize initial costs, and thus increases the calculated fee slightly. Decreasing the levelization period to 10 years increases the fees substantially.

\subsection{FINANCIAL VARIATIONS}

These cases demonstrate the sensitivity of the fee calculation to the selected discount rate and to the assumption that the AFR basins are government financed.

Case 10 - Discount Rate Variation

Tables 13 and 14 shows the fee calculated using a $0.0 \%$ discount rate, and a $10 \%$ discount rate. The results show an increase in calculated fee 
with increased discount rate. The R\&D component is the most sensitive, since these costs precede revenues to a greater extent than those of the other components.

TABLE 13. Calculated Fees with 10\% Discount Rate

\begin{tabular}{|c|c|c|c|}
\hline & Uniform Fee & Disposal Fee & $\begin{array}{l}\text { Storage Pius } \\
\text { Disposal Fee }\end{array}$ \\
\hline AFR Easin & 16.50 & 0 & 115.50 \\
\hline Transportation & 3.50 & 0 & 23.00 \\
\hline Packaging & 30.50 & 41.00 & 30.00 \\
\hline Repository & 59.00 & 62.00 & 45.50 \\
\hline$R \& D$ & 43.50 & 43.50 & 43.50 \\
\hline Overhead & 7.00 & 7.00 & 7.00 \\
\hline TOTAL & 160.00 & 153.50 & 264.50 \\
\hline
\end{tabular}

TABLE 14. Calcuiated Fee with 0\% Discount Rate

\begin{tabular}{|c|c|c|c|}
\hline & Uniform Fee & Disposal Fee & $\begin{array}{l}\text { Storage Plus } \\
\text { Disposal Fee }\end{array}$ \\
\hline AFR Bāsin & 5.00 & 0 & 86.50 \\
\hline Transportation & 2.00 & 0 & 31.50 \\
\hline Packaging & 23.00 & 23.00 & 23.00 \\
\hline Repository & 37.50 & 37.50 & 37.50 \\
\hline$R \& D$ & 10.00 & 10.00 & 10.00 \\
\hline Overhead & 4.00 & 4.00 & 4.00 \\
\hline TOTAL & 81.50 & 74.50 & 192.50 \\
\hline
\end{tabular}

Case 11 - Government Financed AFR Basins

The cash flow for the reference case was altered to reflect the private industry financing of the capital costs of the AFR basin. It was assumed that the government would pay a commercial operator an annual fee for the use of the basin. This fee would be sufficient to allow the operator an after tax profit on his investment. Table 15 shows that private financing increases the AFR basin component of the fees approximately $40 \%$. 
TABLE 15. Privately Financed AFR Bas in

$$
\text { Uniform Fee Disposal Fee } \begin{aligned}
& \text { Storage Plus } \\
& \text { Disposal Fee }
\end{aligned}
$$

AFR Basin

Transportation

Packaging

Repository

R\&D

Overhead

TOTAL
15.50

2.50

33.00

50.00

26.50

5.50

133.00

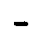

$-$

33.50

51.50

25.50

5.50

117.00
148.00

26.00

27.50

42.00

26.50

5.50

275.50

Summary of Financial Variation Sensitivities

The sensitivity of the fee to the discount rate was shown to illustrate the relationship between costs and revenues for each charge component, and does not represent an option. Private finaricing of AFR basin capital costs increases the AFR component $40 \%$, but this does not represent a significant variation of the entire fee. 


\subsection{ANALYSIS OF ABNORMAL SYSTEM PERFORMANCE}

To determine the sensitivity of the fee to unexpected variations in logistics and costs, cases were analyzed which simulated unplanned delay of or operational failure at the first repository.

\subsection{UNPLANNED DELAY OF THE FIRST REPOSITORY (CASES 12-13)}

The planned repository delay cases previously analyzed (Cases 5 and 6) were reevaluated assuming that capital costs for the first repository and first packaging facility were incurred as if the repository were starting operation in 1988, and an additional $\$ 75$ million were spent each year from 1988 to eventual startup. This is intended to simulate a cost and schedule overrun at the first repository by continuing the 1988 expenditure rate during the delay period. The results of these calculations (Cases 12 and 13) are given in Tables 16 and 17. The impact of the assumed cost penalty is observed in the packaging and repository components. Only the uniform fees are compared, since these are a measure of total system cost.

TABLE 16. Uniform Fee for Unplanned Delay of First Repository Unti7 $1990(\$ / \mathrm{kg})$

$\begin{array}{lrrr} & \text { Unplanned } & & \text { Planned } \\ \text { AFR Basin } & 14.50 & & 14.50 \\ \text { Transportation } & 4.00 & & 4.00 \\ \text { Packaging } & 33.50 & & 32.00 \\ \text { Repository } & 52.50 & & 50.00 \\ \text { R\&D } & 34.50 & & 34.50 \\ \text { Overhead } & 7.50 & & 7.50 \\ \quad \text { TOTAL } & 146.50 & & 142.50\end{array}$


TABLE 17. Uniform Fee for Unplanned Delay of

First Repository Until $1993(\$ / \mathrm{kg})$

$\begin{array}{lrrr} & \text { Unplanned } & & \text { Planned } \\ \text { AFR Basin } & 26.00 & & 26.00 \\ \text { Transportation } & 7.50 & 7.50 \\ \text { Packaging } & 35.50 & & 28.50 \\ \text { Repository } & 58.50 & & 48.50 \\ \text { R\&D } & 54.50 & & 54.50 \\ \text { Overhead } & \underline{11.50} & & \underline{11.50} \\ \quad & 193.50 & & 176.50\end{array}$

\subsection{FAILURE OF THE FIRST REPOSITORY}

Case 14 - Preoperational Failure of the Initial Repository

This case assumes that the first repository is constructed normally, but prior to operation is deemed unusable for underground disposal. The existing above-ground facilities are assumed to be usable. An above-ground storage yard is constructed to temporarily store packaged fuel. During the construction period of the temporary storage yard, AFR bas in facilities continue to store unpackaged fuel. The first operational (the second repository from the reference case) repository becomes available in 1997. The backup repository replacing the failed repository also becomes available in 1997. Fuel is assumed received by the government as in the reference case. Costs for al 1 incremental spent fuel management activities have been included in the component costs in Table 18. Higher transportation costs are due to shipment of encapsulated fuel from the failed repository site to the replacement repository. The fee component for the failed repository includes all costs incurred prior to the time of the failure and all costs for constructing and operating the temporary storage yard. 


\section{TABLE 12. Calculated Fee for a Prenperational \\ Failure of the Initial Repository \\ $(\$ / \mathrm{kg})$}

\section{Uniform Fee}

\begin{tabular}{lr} 
AFR Basin & 11.00 \\
Transportation & 16.00 \\
Packaging & 33.50 \\
Failed Repository & 39.50 \\
Repository & 31.00 \\
RR:D & 26.50 \\
Overhead & 5.50 \\
\multicolumn{1}{c}{ TOTAL } & \\
&
\end{tabular}

Case 15 - Failure of the Initial Repository During Operation

This case represents a situation in which the repositery operates as designed for the first five years, but prior to the sixth year it is determined that fuel may no longer be placed underground. The surface facilities are still assumed to be operational and a surface storage yard is constructed. Fuel received after the initial repository fails is packaged and held at the surface storage yard. Fuel already underground at the failed repository is retrieved and stored in the surface storage yard. A replacement repository is constructed by 2000 and all fuel at the initial repository site is ultimately deposited there. As before, transportation costs are higher due to shipment of encapsulated fuel from the storage yard to the replacement repository. The fee component for the failed repository (Table 19) includes a11 costs incurred prior to the time of failure and estimates of all costs incurred unloading and decommissioning the failed repository. 
TABLE 19. Calculated Fee for a Failure of the Initial

Repository During Operation $(\$ / \mathrm{kg})$

\section{Uniform Fee}

\begin{tabular}{lr} 
ARF Basin & 17.00 \\
Transportation & 31.50 \\
Packaging & 33.00 \\
Failed Repository & 51.00 \\
Repository & 26.50 \\
R\&D & 26.50 \\
Overhead & 5.50 \\
\multicolumn{1}{c}{ TOTAL } & 185.00
\end{tabular}

Summary of Abnormal System Performance Sensitivities

These cases are different from the variations analyzed previously in the sense that advance knowledge of a failure or delay would be required in order to collect the correct fee for the entire period. Therefore, they do not reprasent normal fee calculations, but instead illustrate the relationship between the reference fee and a fee sufficient to fuily recover expenses associated with the abnormal events considered.

In the delay cases the arnount of fuel received prior to 2000 decrease from the reference case. This magnifies the impact of cost increases, since there is less fuel over which to levelize fixed costs. The repository failure cases were analyzed assuming the reference case fuel receipt schedule. This was dore to provide a basis for comparison with the reference case. 


\section{REFERENCES}

1. National Waste Terminal Storage Economic Study, Part 2: Spent Fuel Management Pricing. (Draft), Prepared by TRW Energy Systems for the Office of Waste Isolation, Union Carbide, Nuclear Division, March, 1978.

2. Economics of Water Basin Storage of Spent LWR Fuel, DPST-ISFS-78-1, Technical Division, Savannah River Laboratory, February 6, 1978.

3. Spent Unreprocessed Fuel Facility Engineering Studies, RHO-LD-2, Rockwe 71 Hanford Operations, February 1978.

4. Generic Environmental Impact Statement on Handling and Storage of Spent Light Water Power Reactor Fuel, NUREG-0404, Vo1. 2, Appendices, U.S. Nuclear Regulatory Commission, March 1978. 


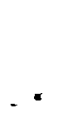


APPENDIX A

FACILITY COST DATA 


\section{FACILITY COST DATA}

The cost data used for spent fuel storage/disposal facilities are presented in this appendix. Preliminary engineering cost estimates were used to modei expenditure patterns for the various facilities. These estimates are not detailed in the budget sense and should not be interpreted as such.

The AFR basin cost data were excerpts from economic analyses of water basin storage performed at Savannah River Laboratory. Since one of the cases assumed private ownership of the AFR basin, assumptions about the financial posture of the private owner were necessary. A $25 \% / 75 \%$ debt equity ratio, $8 \%$ loan rate, $12 \%$ return on equity, $50 \%$ tax rate, and $6 \%$ investment tax credit were assumed. ${ }^{(2)}$

Transportation costs (for transporting fuel from AFR basins to the repository) were provided by DOE, based on work being performed by TRW. (1)

Packaging costs were adapted from cost estimates developed for the Spent Fuel Handling and Packaging Project, managed for DOE by Rockwell Hanford Operations. (3) Cost estimates for packaging fuel for the drywell interim storage were modified where appropriate for use in this study. The cost data for above-ground storage in the repository failure cases was also adapted from this source.

Repository costs were modeled using preliminary cost estimates developed for the Office of Waste Isolation. 
TABLE A-1. 10,000 MT Capacity AFR

Facility: $\quad 10,000$ MT Capacity AFR

Total Capacity: $\quad 10,000 \mathrm{MT}$

Maximum Receipt Rate: 3,000 MT/Year

Capital Construction Cost ${ }^{(a)}: \quad 322$

CAPITAL COSTS

\begin{tabular}{|c|c|c|c|c|c|}
\hline \multirow[b]{2}{*}{ Capital Item } & \multirow[b]{2}{*}{ Cost } & \multicolumn{2}{|r|}{ Occurrence } & & \multirow[b]{2}{*}{ Comments } \\
\hline & & Pre-Startup & During Operation & Post-Shutdown & \\
\hline Capital Construction & 10 & -4 & - & - & \\
\hline Capital Construction & 17 & -3 & - & - & \\
\hline Capital Construction & 111 & -2 & - & - & \\
\hline Capital Construction & 184 & -1 & - & - & Includes Baskets \\
\hline
\end{tabular}

QPERATING COSTS

\begin{tabular}{lccccc}
\multicolumn{1}{c}{ Item } & Cost & Pre-Startup & During Docration & Post-Shutdown & Comments \\
\hline Operating Cost & 5 & & - & Every Year & - \\
Operating Cost & 3 & Incurred when facility is loaded or unloaded. \\
Decomissioning & 28 & - & - & +1
\end{tabular}

(a) A11 Costs are in millions of 1978 dollars. 


\title{
TABLE A-2. 5,000 MT Capacity AFR
}

\author{
Facility: $\quad 5,000$ MT Capacity AFR \\ Total Capacity: $\quad 5,000$ MT \\ Maximum Receipt Rate: 2,000 MT/Year \\ Capital Construction Cost ${ }^{(a)}: \quad 201$
}

CAPITAL COSTS

Occurrence

\begin{tabular}{lcccccc} 
Capital Item & Cost & Pre-Startup & During Operation & Post-Shutdown & Comments \\
\hline Capital Construction & 10 & & -4 & - & - \\
Capital Construction & 15 & & -3 & - & - \\
Capital Construction & 71 & -2 & - & - & Includes Baskets
\end{tabular}

OPEFATING COSTS

\begin{tabular}{|c|c|c|c|c|c|}
\hline & & & & & \\
\hline Item & Cost & Pre-startup & During Operation & Post-Shutdown & Comments \\
\hline Operating Cost & 4 & - & Every Year & - & \\
\hline Operating Cost & 2 & Incurred whe & facility is loaded & unloaded. & \\
\hline Decommissioning & 20 & - & - & +1 & \\
\hline
\end{tabular}

(a) All costs are in millions of 1978 dollars. 


\title{
TABLE A-3. 1,000 MT AFr Module
}

\author{
Facility: $\quad$ 1,000 MT Capacity AFR Module \\ Total Capacity: $\quad$ 1,000 MT \\ Maximum Receipt Rate: 1,000 MT/Year \\ Capita 7 Construction Cost ${ }^{(a)}: \quad 19.2$
}

CAPITAL COSTS

Occurrence

Capital Item

$\underline{\text { Cos }}$

Capital Construction

19.2

$\frac{\text { Pre-Startu }}{-1}$

During Operation

Post-Shutdown

Comments

Includes Baskets

OPERATING COSTS

Occurrence

$160 m$

Cost Pre-Startup During Operation

Post-Shutdown

Comments

Operating cost is assumed to be included in the base module (accompanying 5,000 or 10,000 MT facility).

(a) A?l costs are in mijlions of 1978 dollars. 
TABLE A-4. Transportation

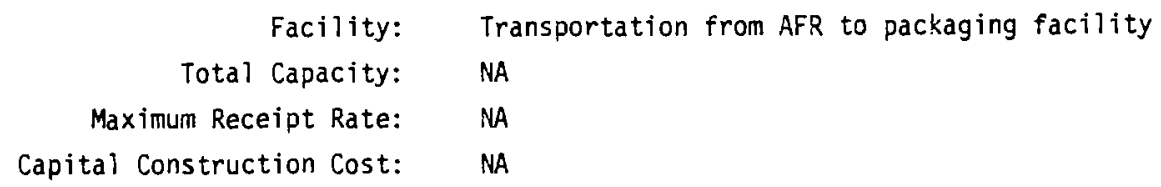

CAPITAL COSTS

Occurrence

Cost Pre-Startup During Operation

Post-Shutdown

Comments

None

OPERATING COSTS

Occurrence

Item

$\underline{\cos t}$

Pre-Startup During Operation

Post-Shutdown

Transportation $31.50 / \mathrm{Kg}$

During AFR unToad

Comments

Round trip cost for 1,600 mile one-way route. 


\section{TABLE A-5. Packaging Facility (Two Components)}

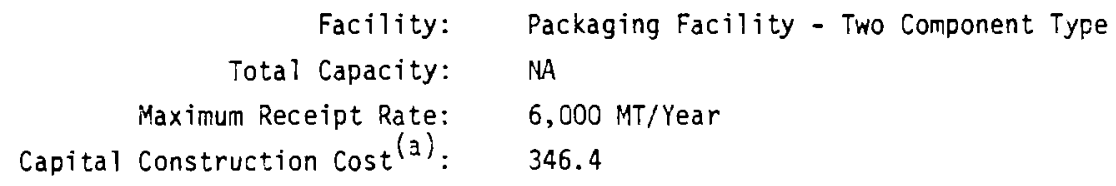

\begin{tabular}{|c|c|c|c|c|c|}
\hline & & & & & \\
\hline Capital Item & $\underline{\operatorname{Cost}}$ & Pre-Startup & During Operation & Post-Shutdown & Comments \\
\hline Capital Construction & 139.2 & -4 & - & - & \\
\hline Capital Construction & 121.2 & -3 & - & - & \\
\hline Capital Construction & 51.4 & -2 & - & - & \\
\hline Capital Construction & 34.6 & -1 & - & - & \\
\hline OPERATING COSTS & & & & & \\
\hline Item & Cost & Pre-startup & During Operation & Post-Shutdown & Comments \\
\hline Fixed Cost & 21.2 & - & Every Year & - & \\
\hline Variable $\cos t$ & $.00384 / C$ & ister & - & - & \\
\hline
\end{tabular}

(a) All costs are in millions of 1978 dollars. 


\section{TABLE A-6. Packaging Facility (Three Components)}

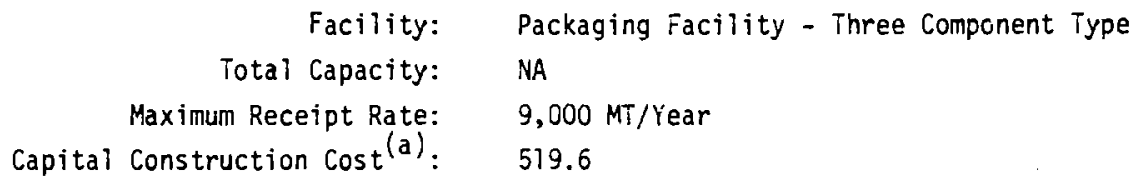

\begin{tabular}{|c|c|c|c|c|c|}
\hline Item & $\operatorname{Cos} t$ & Pre-Startup & During Operation & Post-Shutdown & Comments \\
\hline Fixed Cost & 1. & - & Every Year & - & \\
\hline Variable & .0038 & ister - & - & - & \\
\hline
\end{tabular}

(a) Ali costs are in miliions of 1978 dollars. 


\section{TABLE A-7. Initial Repository - Conservative Design}

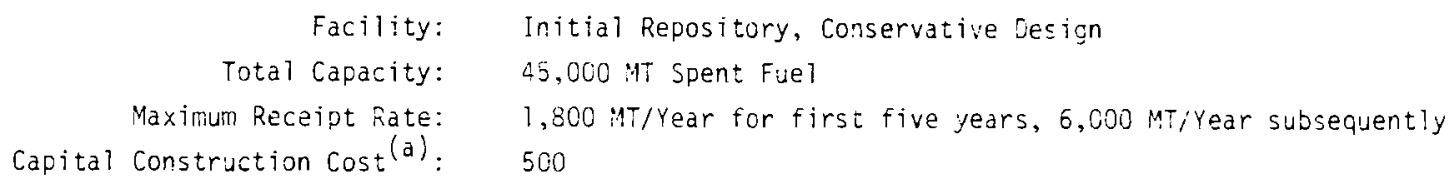

\begin{tabular}{|c|c|c|c|c|c|}
\hline \multirow[b]{2}{*}{ Capital Item } & \multirow[b]{2}{*}{$\underline{\cos t}$} & \multicolumn{3}{|c|}{ Occurrence } & \multirow[b]{2}{*}{ Comments } \\
\hline & & Pre-startup. & During Operation & Post-Shutdown & \\
\hline Capital Construction & 5.00 & -7 & - & - & \\
\hline Capital Construction & 20.00 & -6 & - & - & \\
\hline Capital Construction & 80.00 & -5 & - & - & \\
\hline Capital Construction & 125.00 & -4 & - & - & \\
\hline Capital Construction & 110.00 & -3 & - & - & \\
\hline Capital Construction & 85.00 & $-?$ & - & - & \\
\hline Capital Construction & 75.00 & -1 & - & - & \\
\hline $\begin{array}{l}\text { Capital Equipment } \\
\text { Replacement }\end{array}$ & 2.31 & - & Every Year & - & \\
\hline $\begin{array}{l}\text { Capital Equipment } \\
\text { Replacement }\end{array}$ & 6.00 & - & - & - & $33,600^{(b)}$ \\
\hline $\begin{array}{l}\text { Capital Equitement } \\
\text { Replacenent }\end{array}$ & 11.00 & - & - & - & $122,000^{(b)}$ \\
\hline $\begin{array}{l}\text { Capita? Equipmen: } \\
\text { Replacerrent }\end{array}$ & 10.00 & - & - & - & $84,000^{(b)}$ \\
\hline
\end{tabular}

OPERATING COSTS

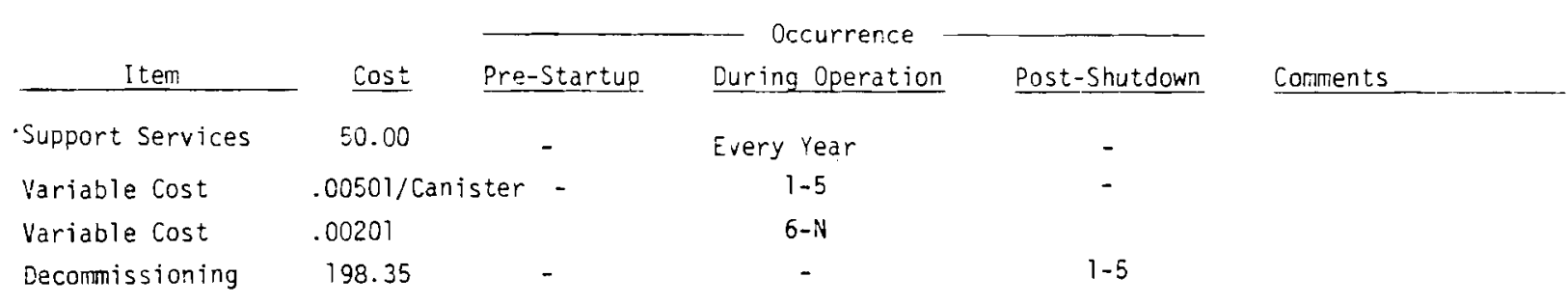

(a) All costs are in millions of 1978 dollars.

(b) Costs occur the year cumulative canisters reach this level. 


\title{
TABLE A-8. Second and Subsequent Repositories
}

\author{
Facility: Repositories built after initial conservative design \\ Total Capacity: $\quad$ 100,000 MT Spent Fuel \\ Maximum Receipt Rate: $\quad 4,500 \mathrm{MT} /$ Year for first three years, 9,000 MT/Year subsequently \\ Capital Construction Cost ${ }^{(a)}: \quad 515$
}

\section{CAPITAL COSTS}

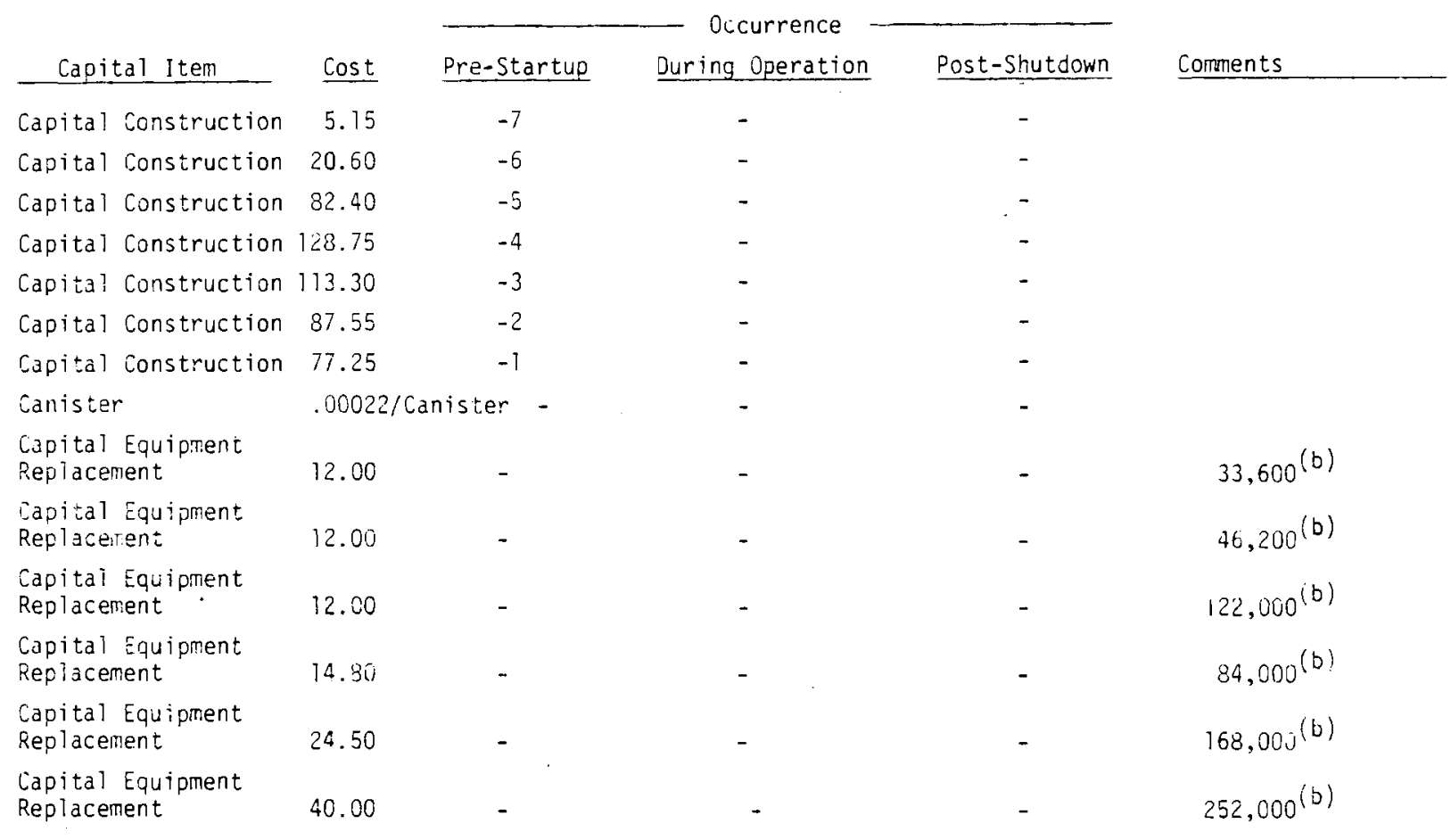

OPERATING COSTS

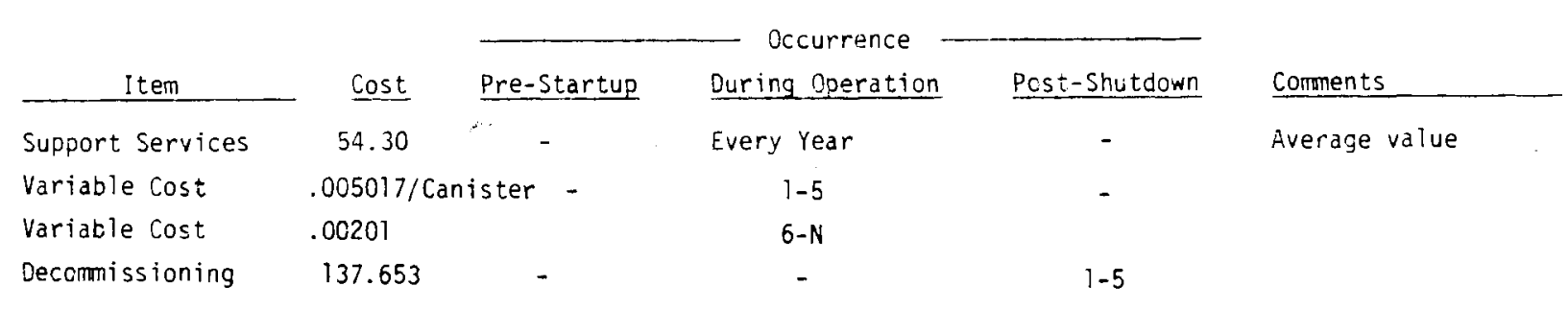

(a) A11 costs are in millions of 1978 dollars.

(b) Costs occur year cumulative canisters reach this level. 


\section{TABLE A-9. Miscellaneous Costs}

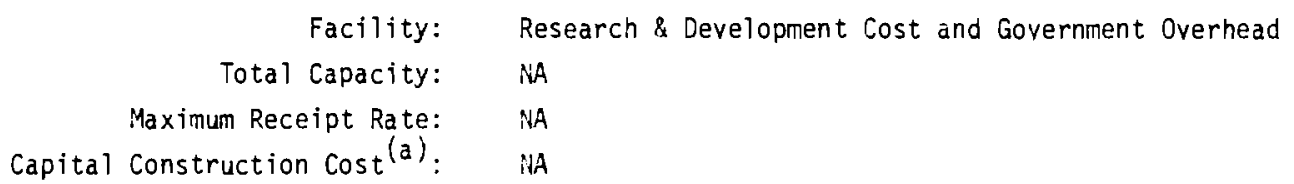

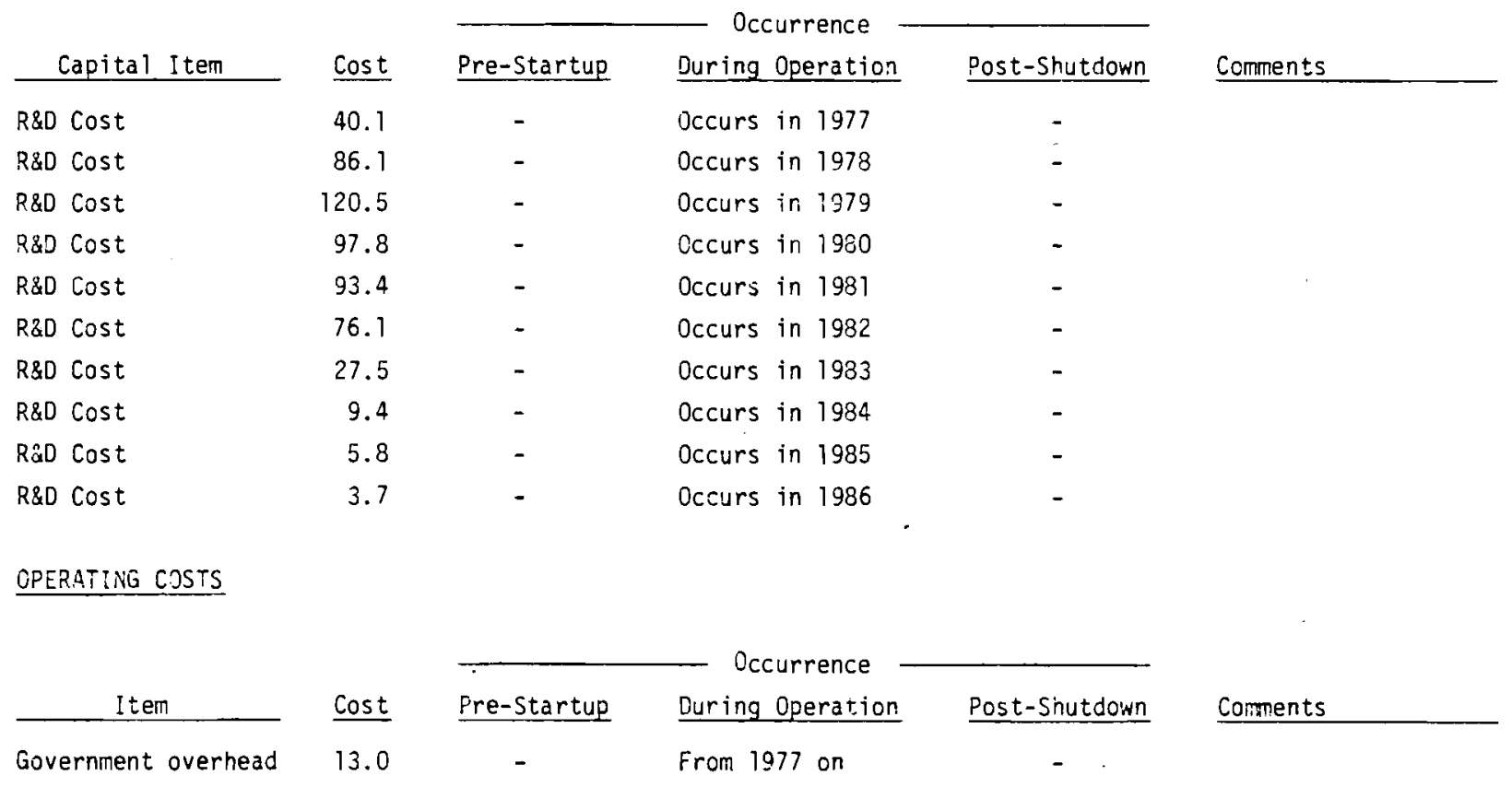

(a) All costs are in millions of 1978 dollars. 
APPENDIX B

SPENT FUEL LOGISTICS 
TABLE B-1. Fue1 Logistics for Case 1
MT

$\begin{array}{lccc} & \text { To AFR } & \text { From AFR } & \text { To Repository } \\ 1983 & 1710 & & \\ 1984 & 860 & & \\ 1985 & 1620 & & \\ 1986 & 1470 & & \\ 1987 & 1780 & & 1800 \\ 1988 & 210 & & 1800 \\ 1989 & 280 & & 1800 \\ 1990 & 920 & & 1800 \\ 1991 & 920 & & 1800 \\ 1992 & 920 & & 6000 \\ 1993 & & 3000 & 6000 \\ 1994 & & 3000 & 6000 \\ 1995 & & 3000 & 6000 \\ 1991 & & 1690 & 6000 \\ 1997 & & & 6000 \\ 1998 & & & 6000 \\ 1999 & & & 6000 \\ 2000 & & & \end{array}$

\section{TABLE B-2. Fue1 Logistics for Case 2 MT}

$\begin{array}{lrrr} & \text { To AFR } & \text { From AFR } & \text { To Repository } \\ 1983 & 1378 & & \\ 1984 & 729 & & \\ 1985 & 906 & & \\ 1986 & 1005 & & \\ 1987 & 1055 & & \\ 1988 & & 602 & 1800 \\ 1989 & & 548 & 1800 \\ 1990 & & 950 & 1800 \\ 1991 & & 805 & 1800 \\ 1992 & & 789 & 1800 \\ 1993 & & 1379 & 6000 \\ 1994 & & & 6000 \\ 1995 & & & 6000 \\ 1996 & & & 6000 \\ 1997 & & & 6000 \\ 1998 & & & 6000 \\ 1999 & & & 6000 \\ 1000 & & & 6000\end{array}$


IABLE B-3. Fuel Logistics for case 3 MT

\begin{tabular}{|c|c|c|c|}
\hline & TO AFR & From A.CR & To Repository \\
\hline 1383 & 978 & & \\
\hline 1984 & 429 & & \\
\hline 1385 & 506 & & \\
\hline 1986 & 605 & & \\
\hline$\lcm{987}$ & 655 & & \\
\hline 1989 & & 1122 & i 800 \\
\hline 1989 & & 1048 & 1800 \\
\hline 1990 & & 950 & 1800 \\
\hline 1991 & & 73 & 1058 \\
\hline 1992 & & & $101 ?$ \\
\hline 1993 & & & 1117 \\
\hline 1994 & & & 1799 \\
\hline 1995 & & & 1320 \\
\hline 1995 & & & 1427 \\
\hline 1997 & & & 1571 \\
\hline 1998 & & & 1714 \\
\hline 1999 & & & $260 \div$ \\
\hline 2000 & & & 2902 \\
\hline
\end{tabular}

\section{TABLE B-4. Fuel Logistics for Case 4} MT

$\begin{array}{llll} & \text { To AFR } & \text { From AFR } & \text { To Repository } \\ 1983 & 3040 & & \\ 1984 & 2783 & & \\ 1985 & 1412 & & \\ 1986 & 1661 & & \\ 1987 & 1944 & & 1800 \\ 1988 & 310 & & 1800 \\ 1989 & 461 & & 1300 \\ 1990 & 537 & & 1500 \\ 1931 & 544 & & 1300 \\ 1992 & 451 & & 6000 \\ 1993 & & 2787 & 5000 \\ 1994 & & 2439 & 5000 \\ 1995 & & 2040 & 5000 \\ 1996 & & 1643 & 5000 \\ 1997 & & 1257 & 8149 \\ 1998 & & 2937 & 5652 \\ 1999 & & & 6089 \\ 2000 & & & \end{array}$


TABLE B-5. Fuel Logistics for Case 5 MT

$\begin{array}{lccc} & \text { To AFR } & \text { From AFR } & \text { To Repository } \\ 1983 & 978 & & \\ 1984 & 506 & & \\ 1986 & 605 & & \\ 1987 & 655 & & \\ 1988 & 698 & & \\ 1989 & 752 & & \\ 1990 & & 950 & 1800 \\ 1991 & & 805 & 1800 \\ 1992 & & 789 & 1800 \\ 1993 & & 689 & 1800 \\ 1994 & & 601 & 1800 \\ 1995 & & 789 & 6000 \\ 1996 & & & 6000 \\ 1997 & & & 6000 \\ 1998 & & & 6000 \\ 1999 & & & 6000 \\ 2000 & & & 6000\end{array}$

TABLE B-6. Fuel Logistics for Case 6 MT

\begin{tabular}{lccc} 
& To AFR & From AFR & To Repository \\
\cline { 2 - 2 } 1983 & 978 & & \\
1984 & 429 & & \\
1985 & 506 & & \\
1986 & 605 & & \\
1987 & 655 & & \\
1988 & 698 & & \\
1989 & 752 & & \\
1990 & 850 & & \\
1997 & 995 & & 1800 \\
1992 & 1011 & & 1800 \\
1993 & & 589 & 1800 \\
1994 & & 601 & 1800 \\
1995 & & 480 & 1800 \\
1996 & & 373 & 6000 \\
1997 & & 229 & 6000 \\
19.99 & & 4286 & 6000 \\
1999 & & 821 & \\
2000 & & &
\end{tabular}




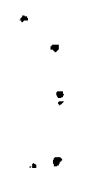




\section{DISTRIBUTION}

No. of

Copies

OFFSITE

A. A. Churm

DOE Chicago Patent Group

9800 South Cass Avenue

Argonne, IL 60439

W. W. Ballard

Department of Energy

Washington, DC 20545

J. J. Firoe

Department of Energy Washington, DC 20545

100 M. J. Lawrence

Department of Energy

Washington, OC 20545

A. J. Snyder

Department of Energy

Washington, DC 20545

J. P. Therault

Department of Energy

Washington, DC 20545

27 DOE Technical Information Center
No. of

Copies

ONSITE

DOE Richland Operations Office

R. B. Goranson

H. E. Ransom

Pacific Northwest Laboratory

N. E. Carter

L. L. Clark

R. M. Fleischman (10)

M. A. Lewallen (10)

R. C. Liikala

R. W. Mckee

E. T. Merril1 (10)

A. M. Platt

M. K. White (10)

Technical Information Files (5)

Publishing Coordination (2) 

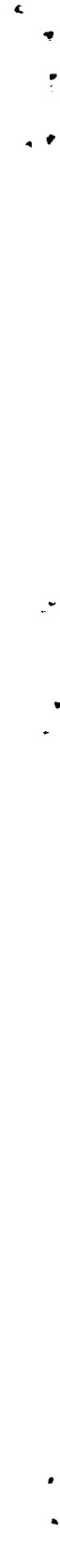